\title{
Impact of Relationship Marketing Variables on Brand Resonance: Mediating Role of Brand Attitude
}

\author{
Divyasre. V. S, Ramya .J
}

\begin{abstract}
Relationship Marketing has got its values strongly rooted in business and market place right from the year 1983. It is the core sphere of operation for all kinds of trade and no organization overlooks this concept. Holding this importance of Relationship Marketing as a core idea, the study aims at discerning the impact of Relationship Marketing Variables on Brand Resonance. Brand Resonance is yet another dominant state of psychological connect which every company would like to establish with the customers. The Relationship Marketing Variables Trust, conflict handling, empathy and Satisfaction are considered for the analysis. Brand Loyalty, Brand Community, Brand Engagement and Brand Attachment are the variables of Brand Resonance. Focusing on the relationship marketing variables that contributes towards high brand resonance would enable companies to contemplate on these profit enabling areas that eventually leads to a sustenance growth for the organization. Indian Shopping Websites has been given the prime importance in this study and data has been collected from 515 users of these websites. Multiple regression is employed as a main tool to examine the influential effect and for mediation analysis. The mediating effects of brand attitude over brand resonance is also examined in this study. Drifting from the traditional view of customer satisfaction influencing Brand Loyalty, this study has found Empathy as the most influential factor on Brand Resonance followed by Conflict handling and Trust. Brand Attitude strongly mediates the relationship between relationship marketing dimensions and Brand Resonance.
\end{abstract}

Keywords: Relationship Marketing, Brand Attitude, Brand Resonance

\section{INTRODUCTION:}

Online retailing has completely revolutionized the shopping Industry and has given customers a different shopping experience. E retailing industry is currently facing a rapid growth of $51 \%$ per year and is expected to generate a revenue of US $\$ 200$ billion by 2026. Currently the revenue of e commerce Industry is US\$38.5 billion. In such a dynamically changing industry with strong players like amazon, Flipkart, Snap Deal, Myntra etc. competing, it is a great challenge to retain customers. Today's consumers before purchasing a product, analyze and compare the features of the product, prices, return policies, shipping information and payment options (Burke 2002) ${ }^{1}$.

Revised Manuscript Received on December 30, 2019.

* Correspondence Author

Dr. V. S. Divyasre*, Assistant Professor, Department of Business Administration, SRM Institute of Science and Technology, Chennai, India. divyasrevs@gmail.com

Dr. J. Ramya, Assistant Professor, Department of Business Administration, SRM Institute of Science and Technology, Chennai,India. ramya.jayaram80@gmail.com

(c) The Authors. Published by Blue Eyes Intelligence Engineering and Sciences Publication (BEIESP). This is an open access article under the CC BY-NC-ND license (http://creativecommons.org/licenses/by-nc-nd/4.0/)
As the customers gain experience in e commerce, online shopping has witnessed a shift from transactional exchange to relation based exchange (Palmatier, 2017) ${ }^{2}$. So it is believed that Relationship Marketing plays an important role in developing concrete relationships with e retail customers (Berry \& Bendapudi, 1997) ${ }^{3}$. Eventually, the e retailers have started to establish relationship with customers online through online communities believing such an initiative would enhance the performance. But still little researches have been conducted to evaluate the effectiveness of Relationship Marketing (Sharma \& Sheth, 2016) 4 .

Brand Resonance defines the customers relationship with the brand and the level of "sync" they establish with the brand (Keller, 2008) ${ }^{5}$. It plays a significant role in CRM and for building a strong brand equity with the customers (Moore \& Wurster, 2007) ${ }^{6}$. When the brand resonance is high, customers exhibit high levels of loyalty which in turn enables them to have a close interaction with the chosen brand.

Brand Attitude are predispositions that are learned which has an impact on the customers to have favourable and unfavourable responses for the brands (Wilkie, 1994) ${ }^{7}$. Attitudes are formed with equal contribution of experience and information. The attitude formed by these two factors influence the customers judgements over the brand (Meyer, 2008) ${ }^{8}$. Previous research supports the positive relationship between Brand Attitude and Relationship Marketing strategies that involve two way communication (Ahn \& Back, 2017) ${ }^{9}$. This proves that empathy and conflict handling, dimensions of relationship marketing share a positive relationship with Brand Attitude.

Brand power is determined by what resides in the minds of the customer which includes Brand Loyalty, Brand Engagement, Brand Community and Brand Attachment (Taghipourian, 2013) ${ }^{10}$. It is considered as one of the most valuable intangible asset of the company. With such great emphasis, Brand Resonance can be employed by the organization to gain competitive advantage (Keller, 2011) ${ }^{11}$. Many companies seek to enhance Brand Resonance dimensions by employing Relationship Marketing (Chang, 2005) ${ }^{12}$. Relationship marketing has more relevance to service organizations compared to product Organizations (Javalgi, 2006) $^{\mathbf{1 3}}$. Inspite of possessing great scope in bringing positive customer experiences and long lasting relationship with customers, researchers have focused little on Brand Resonance. 
Considering this as a research gap, the study aims at determining the influence of Relationship Marketing Dimensions on Brand Resonance and the mediating effect of Brand Attitude between the 2 variables.

\section{REVIEW OF LITERATURE}

From the days of ancient trade, relationship is practiced by numerous business people and it is considered to be an oldest approach of marketing (Gronroos, 1994) ${ }^{\mathbf{1 4}}$. The basic concept of relationship marketing is focused on retaining the existing customers instead of acquiring new customers (Berry 1983) ${ }^{\mathbf{1 5}}$. Rashid (2003) ${ }^{\mathbf{1 6}}$ found nine dimensions that plays pivotal role in the success of Relationship Marketing which includes commitment, experiences, social bonding, fulfilling promises, empathy, customer satisfaction, trust, communication and internal marketing. Ndubisi (2007) ${ }^{\mathbf{1 7}}$ proposes 4 important dimensions which includes communication, trust, conflict handling and commitment in Service Industry. Trust and empathy are one among the four dimensions proposed by Callaghan(1995) ${ }^{\mathbf{1 8}}$. The study carried out by Sin (2005), proved that relationship marketing dimensions were critical for the success of the business. Trust and satisfaction are relationship marketing dimensions considered in many B2B and B2C Context. But empathy, though has supporting evidence in B2B context (Yau, 2000, Chattananon \& Trimetsoontorn, 2009) ${ }^{\mathbf{1 9}}$, the growth of B2C and service industries have paved way for the increasing attention on empathy (Bojei, 2012) ${ }^{\mathbf{2 0}}$.

According to Keller, Brand Resonance has four dimensions which includes Brand Loyalty, Brand attachment, Brand Community and Brand Engagement. Tracing out the linkage between Relationship Marketing Dimensions and Brand Resonance, Brand Attachment is directly influenced by the core factors of Relationship Marketing that includes trust and satisfaction ( Tsai, 2011) $^{21}$. Significant and positive relationship existed between the two factors, Conflict handling and Brand Loyalty through trust and relationship quality (Ndubisi \& Chan, 2005) ${ }^{22}$. When the service providers handle the conflicts of customers satisfactorily, they develop a loyalty towards the company or the brand ( Ndubisi, 2006) ${ }^{\mathbf{2 3}}$. Beyond conflict handling, empathy too fosters loyalty of the customers as per the research conducted by Abdullah and Kanyan (2013) ${ }^{24}$.

Gefen(2003) $)^{25}$ in a study conducted in the field of online shopping portals found that trust enhances the intentions of loyalty towards the brand and thus dependence on control systems are reduced which eventually reduces the transaction costs. Studies carried out in the context of Internet Applications have validated a positive link between loyalty intentions and overall satisfaction (Harris and Goode, 2004) ${ }^{\mathbf{2 6}}$. Moreover, Brand Community research suggest that satisfied relationships of the consumer with the brand encourages them to share their experience with like minded people and thus shares a positive relationship (Algesheimer, 2005) ${ }^{27}$.

(Gashti and Chirani, 2017) ${ }^{28}$ in their study has proved a positive relationship between relationship marketing dimension (bonding, communication, interaction, shared values, empathy and trust) and brand attitude. He suggests that formation of attitude is based on the physical and mind related processes which gets started before product/service purchase and also continues post purchase. Taylor and Hunt (2003) ${ }^{29}$ in their study have found trust to be emerged as a significant antecedent of brand attitude. The study further suggests that brand attitude mediates the relationship between satisfaction and loyalty. Moreover brand attitude has a direct effect created by post consumption. From the past studies it is clear that brand attitude has a positive impact both on relationship marketing dimensions and brand resonance.

\section{Underlying theory - Social Exchange theory}

Social Exchange theory is proposed by Homans (1958) which assists to discern the relation between the social behaviour of individuals and the economic activities. The postulations of the theory suggests that consumer and supplier exchange services and goods just not for money, but also for benefits arising from non monetary factors that includes affection, love, approval and esteem (Cropanzano and Mitchell, 2005) ${ }^{31}$. The theory further suggests that, smooth and cordial relationship between supplier and customer adds utility and incremental value for the brand $(\mathbf{Y o o}, \mathbf{2 0 0 0})^{32}$. This means that when a consumer shares a pleasurable and memorable relationship with the company, eventually a positive image is created in the minds of the customer which results in increase of brand loyalty, an important dimension of Brand Resonance (Lawler, 2001) ${ }^{33}$. Thus based on Social Exchange Theory, the relationship between Relationship Marketing Dimensions and Brand Resonance is proved.

\section{METHODOLOGY}

The nature of the research is descriptive and involves cross sectional design. Sample size for the study is 515 and the primary data is collected using online questionnaires. Individuals who actively use online portals for shopping purpose were selected as sample respondents. Convenience sampling is the sampling method employed as online customers can be conveniently selected based on the ease of access.

The Questionnaire consisted of four constructs ( Trust, empathy, Satisfaction, Conflict handling) under relationship marketing and four constructs (Brand Attachment, Brand Engagement, Brand Community and Brand Loyalty) under Brand Resonance. Five point likert scale has been adopted with varying intensities

Regression Analysis is the statistical tool employed in this study. It is one of the efficient techniques which is used to find the relationship between variables (Bowerman, 1990) ${ }^{34}$. Dependent and independent variable variables are best related using the mathematical model built adopting Regression technique (Draper and Smith, 1981) ${ }^{35}$. The linear regression equation for the independent and dependent variable is represented as

$\mathrm{Y}=\boldsymbol{\alpha}_{0}+\boldsymbol{\alpha}_{1} \mathrm{X}_{1}+\boldsymbol{\alpha}_{2} \mathrm{X}_{2}+\ldots+\boldsymbol{\alpha}_{\mathrm{n}} \mathrm{X}_{\mathrm{n}}$ 
The mediating effects produced by brand attitude between Relationship Marketing variable and Brand Resonance was analyzed using the Multiple Regression Analysis.

\section{HYPOTHESES OF THE STUDY:}

\section{Relationship Marketing and Brand Resonance}

Previous researches in the field of relationship marketing have suggested positive relationship between Brand resonance and relationship marketing. According to Cronin(2000) ${ }^{36}$, a strong positive correlation existed between the two variables in particular between empathy and Brand Loyalty. Jesri (2013) ${ }^{37}$ found that commitment and trust has a positive impact on Brand Resonance. The reason is, as the organizations gains trust of consumers, the consumers create a positive attitude towards the brand and eventually the organization is positioned as a reliable organization in the minds of people. Thus the customer commitment is enhanced which leads to higher levels of brand loyalty. Shaari and Ahmed (2017) ${ }^{38}$ found that Brand Community is strengthened by interactive communication, commitment and trust of the customers. Brand Engagement is strengthened by provoking the consumers through rewards, communication, experiential contents and shared values.

H1: Trust positively influences Brand Resonance

H2: Empathy positively influences Brand Resonance.

H3: Satisfaction positively influences Brand Resonance

H4: Conflict handling positively influences Brand Resonance

\section{Brand Attitude, Relationship Marketing and Brand Resonance:}

According to recent researches conducted in the field of relationship marketing, trust has emerged as an antecedent for Brand Attitude. The relationship between satisfaction and brand loyalty is mediated by brand attitude. Chiou (2004) ${ }^{39}$ investigated and found that both trust and satisfaction are antecedents to brand loyalty. Various researchers have focused on the importance of trust in Relationship Marketing and that trust plays a pervasive role in the enhancement of Brand loyalty. Moreover, Brand Loyalty is considered to possess true loyalty when it is strongly mediated by brand attitude (Kim and Swait, 2013) ${ }^{\mathbf{4 0}}$. The study conducted on the basis of story telling theory and persuasion theory has resulted in a positive impact on brand attitude by empathy and sympathy (Yu \& Chang, 2013) ${ }^{\mathbf{4 1}}$. Based on the evidence of previous researches conducted in the appropriate fields, the following hypotheses were formulated.

H5: Trust positively influences Brand Attitude

H6: Empathy positively influences Brand Attitude

H7: Customer satisfaction positively influences Brand Attitude

H8: Conflict Handling positively influences Brand Attitude.

H9: Brand Attitude positively influences Brand Resonance

H10: Brand Attitude mediates the relationship between Trust and Brand Resonance
H11: Brand Attitude mediates the relationship between Empathy and Brand Resonance

H12: Brand Attitude mediates the relationship between Customer Satisfaction and Brand Resonance

H13: Brand Attitude mediates the relationship between Conflict handling and Brand Resonance

\section{RESEARCH FRAMEWORK:}

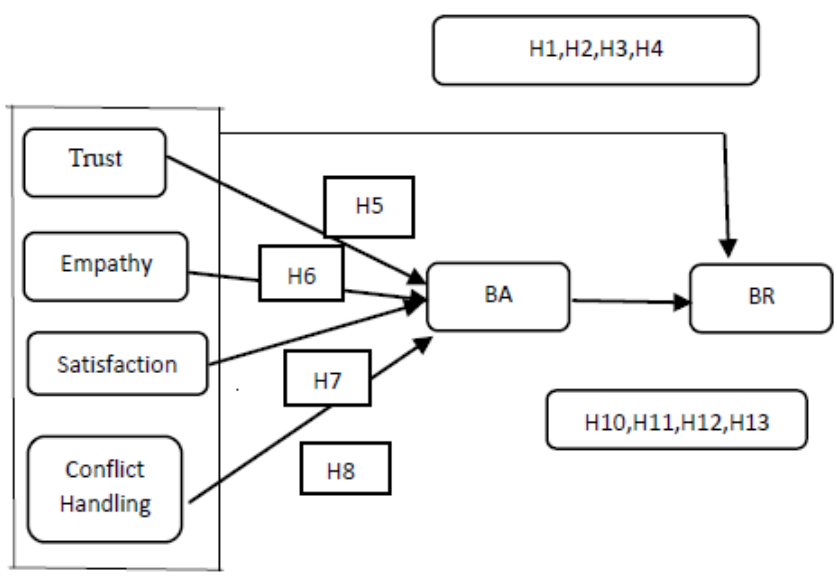

BA - Brand Atttitude, BR - Brand Resonance

\section{RESULT ANALYSIS}

Regression Analysis were carried out to discern the effects between the variables of Relationship Marketing and Brand Resonance. The relationship marketing variables taken into consideration for the analysis are trust, satisfaction, empathy and conflict handling. The analysis was carried out in three stages. Initially the effect of relationship marketing variables over Brand Resonance was analyzed. The second phase included the effect of relationship marketing variables over Brand Attitude. The third phase included the effect of relationship marketing dimensions over brand resonance through brand attitude. The change statistics data was analyzed in order to determine the mediation effects. The effects of Brand Attitude on Brand Resonance was also calculate using regression method

Table 1:Regression Analysis: Relationship Marketing Dimensions and Brand Resonance

\begin{tabular}{|c|l|c|c|c|c|c|}
\hline $\begin{array}{c}\text { Hy } \\
\text { pot } \\
\text { hes } \\
\text { es }\end{array}$ & Variables & $\begin{array}{c}\text { Unsta } \\
\text { ndard } \\
\text { ized } \\
\text { Co } \\
\text { efficie } \\
\text { nt }\end{array}$ & $\begin{array}{c}\text { Std } \\
\text { Error } \\
\text { B }\end{array}$ & $\begin{array}{c}\text { Standar } \\
\text { dized Co } \\
\text { efficient }\end{array}$ & $\begin{array}{c}\text { t } \\
\text { value }\end{array}$ & $\begin{array}{c}\text { p } \\
\text { value }\end{array}$ \\
\hline H1 & $\begin{array}{l}\text { Trust } \rightarrow \\
\text { BR }\end{array}$ & 0.386 & 0.136 & 0.142 & 2.362 & $\begin{array}{c}0.011^{*} \\
*\end{array}$ \\
\hline H2 & $\begin{array}{l}\text { Empathy } \\
\rightarrow \text { BR }\end{array}$ & 1.622 & 0.197 & 0.394 & 8.243 & $\begin{array}{c}0.000^{*} \\
* *\end{array}$ \\
\hline H3 & $\begin{array}{l}\text { Satisfactio } \\
\mathrm{n} \rightarrow \text { BR }\end{array}$ & 0.19 & 0.175 & 0.055 & 1.082 & 0.280 \\
\hline H4 & $\begin{array}{l}\text { Conflict } \\
\text { Handling } \\
\rightarrow \text { BR }\end{array}$ & 0.866 & 0.145 & 0.251 & 5.984 & $\begin{array}{c}0.000^{*} \\
* *\end{array}$ \\
\hline
\end{tabular}




\begin{tabular}{|l|l|}
\cline { 2 - 2 } Adj $\mathbf{R}^{2}$ & $\mathbf{0 . 4 1 4}$ \\
\hline F-value & $\mathbf{9 1 . 9 3 2 * * *}$ \\
\hline R value & $\mathbf{0 . 6 4 7}$ \\
\cline { 2 - 2 } & \\
\hline
\end{tabular}

$* * *$ indicates significance level at $1 \%$ and $* *$ indicates significance level at 5\%

From the above table1 it is evident that since the $\mathrm{R}$ value is 0.647 (greater than 0.5), Relationship Marketing variables and Brand Resonance share a strong relationship. Adjusted $\mathrm{R}^{2}$ value indicates that $41.4 \%$ of the variation in Brand Resonance is caused by Relationship Marketing variables. Except for satisfaction, all the other variables have got a significant p value with level of significance 1\%. Empathy has got the highest co efficient value of 1.622, followed by conflict handling 0.866 and trust 0.386 .This implies that empathy is the highest contributing factor as Brand Resonance increases by 1.622 units for every unit increase in Empathy. Therefore, $\mathrm{H} 1, \mathrm{H} 2$ and $\mathrm{H} 4$ are supported and $\mathrm{H} 3$ is rejected as customer satisfaction has no significance over Brand Resonance.

Brand Resonance $=15.362+1.622$ (Empathy) +0.866 (Conflict handling) +0.386 (Trust)

From table 2 it is evident that all the four variables Trust (0.314), Empathy (0.373), Satisfaction (0.167) and Conflict handling (0.184) has a positive influence on Brand attitude. Thus the hypotheses H5, H6, H7, H8 are supported. Empathy has got the highest positive influence on Brand Attitude, followed by Trust, Conflict handling and Satisfaction

From table 3 it is evident that since the co efficient value (1.238) of Brand Attitude is greater than the other constructs, it is the most influencing factor on Brand Resonance. Table 2 and Table 3 are compared in order to fathom the mediating effects of Brand Attitude. Empathy which was the most influencing factor has been replaced by Brand Attitude. There are changes in the co efficient value, where the value for trust has dropped down from 0.386 to 0.274 , empathy from 1.622 to 1.161 and Conflict handling from 0.866 to 0.639

Table 2:Regression Analysis: Relationship Marketing Dimensions on Brand Attitude(BA)

\begin{tabular}{|c|c|c|c|c|c|c|}
\hline $\begin{array}{c}\text { Hy } \\
\text { pot } \\
\text { hes } \\
\text { es }\end{array}$ & $\begin{array}{c}\text { Variabl } \\
\text { es }\end{array}$ & $\begin{array}{c}\text { Unstand } \\
\text { ardized } \\
\text { Co } \\
\text { efficient }\end{array}$ & $\begin{array}{c}\text { Std } \\
\text { Error of } \\
\text { B }\end{array}$ & $\begin{array}{c}\text { Std. } \\
\text { Co } \\
\text { efficie } \\
\text { nt } \\
\end{array}$ & $\begin{array}{c}\text { t } \\
\text { valu } \\
\mathbf{e}\end{array}$ & $\begin{array}{c}\mathbf{p} \\
\text { value }\end{array}$ \\
\hline & Constant & 5.100 & 0.764 & & $\begin{array}{c}6.67 \\
6\end{array}$ & $\begin{array}{c}0.000 \\
* * *\end{array}$ \\
\hline H5 & $\begin{array}{l}\text { Trust } \\
\rightarrow \text { BA }\end{array}$ & 0.314 & 0.046 & 0.272 & $\begin{array}{c}6.84 \\
1\end{array}$ & $\begin{array}{c}0.000 \\
* * *\end{array}$ \\
\hline H6 & $\begin{array}{l}\text { Empathy } \\
\rightarrow \text { BA }\end{array}$ & 0.373 & 0.054 & 0.292 & $\begin{array}{c}6.92 \\
7\end{array}$ & $\begin{array}{c}0.000 \\
* * *\end{array}$ \\
\hline H7 & $\begin{array}{l}\text { Satisfact } \\
\text { ion } \rightarrow \\
\text { BA }\end{array}$ & 0.167 & 0.048 & 0.155 & $\begin{array}{c}3.47 \\
8 \\
\end{array}$ & $\begin{array}{c}0.001 \\
* * *\end{array}$ \\
\hline H8 & $\begin{array}{l}\text { Conflict } \\
\text { Handlin } \\
\mathrm{g} \rightarrow \mathrm{BA}\end{array}$ & 0.184 & 0.040 & 0.176 & $\begin{array}{c}4.64 \\
6 \\
\end{array}$ & $\begin{array}{c}0.000 \\
* * *\end{array}$ \\
\hline & $\begin{array}{l}\text { Adjuste } \\
\text { d R }^{2}\end{array}$ & \multicolumn{5}{|l|}{0.544} \\
\hline & F-value & \multicolumn{5}{|c|}{$154.059 * * *$} \\
\hline & & \multicolumn{5}{|l|}{0.740} \\
\hline
\end{tabular}

*** indicates significance level at $1 \%$ and $* *$ indicates significance level at 5\%

Table 3 Regression Analysis: Relationship Marketing Dimensions, Brand Attitude and Brand Resonance

\begin{tabular}{|c|c|c|c|c|c|c|}
\hline $\begin{array}{l}\text { Hyp } \\
\text { othe } \\
\text { ses }\end{array}$ & $\begin{array}{l}\text { Indirect } \\
\text { effect }\end{array}$ & $\begin{array}{c}\text { Unstand } \\
\text { ardized } \\
\text { Co } \\
\text { efficient }\end{array}$ & $\begin{array}{c}\text { Standar } \\
\text { d Error } \\
\text { of B }\end{array}$ & $\begin{array}{c}\text { Stand } \\
\text { ardize } \\
\text { d Co } \\
\text { efficie } \\
\text { nt }\end{array}$ & $\begin{array}{c}\text { t } \\
\text { valu } \\
\text { e }\end{array}$ & $\begin{array}{c}\mathbf{p} \\
\text { value }\end{array}$ \\
\hline & Constant & 10.356 & 2.745 & & $\begin{array}{c}4.02 \\
5\end{array}$ & $\begin{array}{c}0.000^{*} \\
* *\end{array}$ \\
\hline H10 & $\begin{array}{l}\text { Trust } \rightarrow \text { BA } \\
\rightarrow \text { BR }\end{array}$ & 0.274 & 0.145 & 0.116 & $\begin{array}{c}2.15 \\
8 \\
\end{array}$ & $\begin{array}{c}0.023^{*} \\
* \\
\end{array}$ \\
\hline H11 & $\begin{array}{l}\text { Empathy } \\
\rightarrow \text { BA } \rightarrow \\
\text { BR }\end{array}$ & 1.161 & 0.194 & 0.282 & $\begin{array}{c}5.98 \\
7\end{array}$ & $\begin{array}{c}0.000^{*} \\
* *\end{array}$ \\
\hline H12 & $\begin{array}{l}\text { Satisfactio } \\
\mathrm{n} \rightarrow \mathrm{BA} \\
\rightarrow \mathrm{BR}\end{array}$ & -0.17 & 0.167 & -0.005 & $\begin{array}{c}0.10 \\
0 \\
\end{array}$ & 0.920 \\
\hline H13 & $\begin{array}{l}\text { Conflict } \\
\text { Handling } \\
\rightarrow \mathrm{BA} \rightarrow \\
\mathrm{BR} \\
\end{array}$ & 0.639 & 0.139 & 0.189 & $\begin{array}{c}4.58 \\
8\end{array}$ & $\begin{array}{c}0.000^{*} \\
* *\end{array}$ \\
\hline & $\begin{array}{l}\text { Brand } \\
\text { Attitude } \\
\rightarrow \text { BR }\end{array}$ & 1.238 & 0.153 & 0.383 & $\begin{array}{c}8.11 \\
3\end{array}$ & $\begin{array}{c}0.000^{*} \\
* *\end{array}$ \\
\hline & $\begin{array}{l}\text { Adjusted } \\
\mathbf{R}^{2} \\
\end{array}$ & \multicolumn{5}{|l|}{0.480} \\
\hline & F-value & \multicolumn{5}{|l|}{$96.060^{* * *}$} \\
\hline & $R$ value & \multicolumn{5}{|l|}{0.697} \\
\hline
\end{tabular}

$5 \%$

Thus hypotheses H10, H11 and H13 are supported and H12 is rejected as the $\mathrm{p}$ value is not significant.

Table 4 Change Statistics

\begin{tabular}{|c|c|c|c|c|}
\hline Model & $\begin{array}{c}\text { Value of } \\
\mathbf{R}\end{array}$ & $\begin{array}{c}\text { Value of } \\
\mathbf{R}^{\mathbf{2}}\end{array}$ & $\begin{array}{c}\text { Adjusted } \\
\mathbf{R}^{\mathbf{2}}\end{array}$ & F value \\
\hline 1 & 0.647 & 0.419 & 0.414 & $91.932^{* * *}$ \\
\hline 2 & 0.697 & 0.485 & 0.480 & $96.06^{* * *}$ \\
\hline
\end{tabular}

*** indicates significance level at $1 \%$ and **indicates significance level at 5\%

The table 4 indicates the change statistic of the effect of Relationship marketing variables on Brand Resonance with and without Brand Attitude as the mediator. With the changes in the value of $R, R^{2}$ and adjusted $R^{2}$, it is clearly evident that Brand Attitude mediates the relationship between Relationship marketing and Brand Resonance.

Table 5 :Regression Analysis: Brand Attitude and Brand Resonance

\begin{tabular}{|l|c|c|c|c|c|}
\hline \multicolumn{1}{|c|}{ Variables } & $\begin{array}{c}\text { Unstd. } \\
\text { Co } \\
\text { efficien } \\
\mathbf{t}\end{array}$ & $\begin{array}{c}\text { Std } \\
\text { Error } \\
\text { of B }\end{array}$ & $\begin{array}{c}\text { Std. } \\
\text { Co } \\
\text { effic } \\
\text { ient }\end{array}$ & t value & $\begin{array}{c}\text { p } \\
\text { value }\end{array}$ \\
\hline Constant & 12.941 & 2.791 & & 4.637 & $\begin{array}{c}0.000 \\
* * *\end{array}$ \\
\hline Brand Attitude & 1.259 & 0.156 & $\begin{array}{c}0.39 \\
0\end{array}$ & 8.079 & $\begin{array}{c}0.000 \\
* * *\end{array}$ \\
\hline Adjusted $\mathbf{R}^{\mathbf{2}}$ & $\mathbf{0 . 4 4 9}$ & \multicolumn{5}{|l}{} \\
\hline F-value & $\mathbf{2 1 0 . 1 8 0 * * *}$ \\
\hline
\end{tabular}


*** indicates significance level at $1 \%$ and $* *$ indicates significance level at $5 \%$

The above table suggests that Brand Attitude positively influences Brand Resonance as the co efficient value 1.259 is significant with p value 0.000 . Thus hypotheses $\mathbf{H 9}$ is supported.

\section{CONCLUSION AND FUTURE WORK}

The findings of this study has a shift from the traditional findings. Earlier online shopping portals placed more emphasis on Customer Satisfaction to drive Brand equity and Brand resonance. As the customers preference for online shopping dimensions has confronted a shift in the recent years, the influential effects too has encountered a transformation. As far as the service industry is concerned and in particular, e commerce industry, empathy and conflict handling plays a vital role as the concept of return policy has gained importance. The online shopping portals should focus on relationship marketing strategies and formulation of a system that would handle the grievances of the customers efficiently. Not even a single grievance of the customer should be overlooked upon. Online shopping Industry is transforming at a fast pace in which product differentiation or low cost may not be the critical factors for gaining competitive advantage but strategies that would empathize with the customers and handle their conflicts would be the corner stone for success. The noteworthy finding is that customer satisfaction has no direct influence on Brand resonance and is no longer considered as a significant variable enhancing Brand Resonance. This finding is in congruence with the recent studies where customer satisfaction has no direct impact on the variables of Brand Resonance. As brand attitude mediates the relationship between the two variables, it is imperative for the organizations to position themselves strongly in the minds of the people so that they feel good about the shopping portal in both the stages of purchase (pre purchase and post purchase). Brand attitude formation starts even before the customer purchases the product/service and so additional focus should be given right from the stage of consumer awareness. The scope for future research can be taken forward by adding other relationship marketing variables and different mediators and moderators.

\section{REFERENCES:}

1. Burke,R.R(2002). Technology and the customer interface: What consumers want in the physical and virtual stores. Journal of the Academy of Marketing Science, 30.

2. Palmatier,R.W (2017). Online relationship formation. Journal of Marketing, 81(3).

3. Berry,L \& Bendapudi,N (1997). Customers motivators for 73(1), 15 -38.

4. Sharma.D \& Sheth,J (2016). Does relationship marketing matter in online retailing: A meta - analytic approach. Journal of the Academy of Marketing Science, 44, 206-217.

5. Keller,K.L(2008). Strategic brand management: Building, measuring and managing brand equity, $3^{\text {rd }}$ ed. Upper Saddle River, NJ:Prentice Hall.

6. Moore,D \& Wurster,D (2007). Self brand connections and brand resonance: the role of gender and consumer emotions in NA. Advances in Consumer Research. 34, 64-66.

7. William,L.Wilkie(1994).Consumer Behaviour.Edition 3, Wiley Publisher

8. Meyer,R.M (2008). Span of management: Concept analysis. Journal of Advanced Nursing, 63(1), 1-113.

9. Ahn,J \& Black,Ki-J (2018). Influence of brand relationship on consumer attitude toward integrated resort brands: a cognitive and maintaining relationships with service providers. Journal of Retailing,

conative perspective. Journal of Travel and Tourism Marketing, 449460.

10. Taghipourian,M.J (2013). The effect of customer satisfaction on word of mouth communication. Research Journal of Applied Sciences, Engineering and Technology, 5(8).

11. Keller,K.L(2011). Strategic Brand management, building, measuring and managing brand equity. Pearson Education India

12. Chang, M.K(2005). Literature derived reference models for the adoption of online shopping. Information and Management. 42(4), 543-559.

13. Javalgi , R.G., Martin,C.L \& Young,R.B(2006). Marketing research, market orientation and customer relationship management: a framework and implications for service providers. Journal of Services Marketing. 20(1), 12-23.

14. Gronroos,C(1994). From marketing mix to relationship marketing towardsa paradigm shift in marketing. Australian Marketing Journal, 2, 9-29.

15. Berry,L.L(1983). Relationship Marketing. Emerging Perspectives of Services Marketing, American Marketing Association, Chicago, IL, 8-25.

16. Rashid,T(2003). Relationship marketing: case studies of personal experiences of eating out. British food journal. 105(10), 742-750.

17. Ndubisi, N.L (2007). Relationship marketing and consumer loyalty. Marketing Intelligence and Planning, 25(1), 98-106.

18. Callaghan,M.,Mc Phail,J \& Yau,O.H.M(1995). Dimensions of relationship marketing orientation: an empirical exposition. Proceedings of the $7^{\text {th }}$ Biannual World Marketing Congress, Melbourne, Australia, 10-65.

19. Yau, O.H.M., Fetridge, P.R., Chow, R.P.M., Tse, A.C.B(2000). Is relationship marketing for everyone. European Journal of Marketing, 34(9).

20. Bojei,J \& Hoo,W.C (2012). Brand equity and current use as the new horizon for repurchase intention of smartphones. International Journal of Business and Society. 13(1), 33-48.

21. Tsai,S.P(2011). Strategic relationship management and service brand marketing. European Journal of Marketing, 45(7), 1194 - 1213.

22. Ndubisi,N.O \& Chan,K.W(2005). Factorial and discriminant analysis of the underpinnings of relationship marketing and custome satisfaction. International Journal of Bank Marketing, 23(3), 542-557.

23. Ndubisi,N.O(2006). Effect of gender on customer loyalty: a relationship marketing approach. Marketing Intelligence and Planning, 24(1), 48-61.

24. Abdullah,F \& Kanyan,A (2013). Managing the dimensions of relationship marketing in the food service industry. Journal of Pengurusan, 37.

25. Gefen, $\mathrm{D}(2003)$. Trust and TAM in online shopping: an integrated approach model. MIS Quarterly, 27(1), 51-90.

26. Harris,L.C \& Goode,M.M.H (2004). The four levels of loyalty and the pivotal role of trust: A study of online service dynamics. Journal of Retailing. 80(2), 139-158.

27. Algesheimer,R.,Dholakia,P\& Herrmann, $A(2005)$. The social influence of brand community: evidence from European car clubs. Journal of Marketing, 69(4).

28. Gashti,J.Z \& Chirani,I(2017). Study of the impact of relationship marketing on the consumer attitude with emphasis on the role of advertising effectiveness. Journal of Internet Banking and Commerce, 22(8).

29. Taylor, S.A \& Hunter, A(2003). An exploratory investigation into the antecedents of satisfaction, brand attitude and loyalty within the B2B e CRM industry. Journal of Consumer Satisfaction, Dissatisfaction and Complaining Behaviour, 16, 19-35.

30. Homans, G.C(1958). Social behaviour as exchange. American Journal of Sociology, 63(6), 597-606.

31. Cropanzano, R \& Mitchell, M,S(2005). Social Exchange Theory: An Interdisciplinary Review. Journal of Management, 31(6), 874-900.

32. Yoo,B., Donthu,N., Lee,S (2000). An examination of selected marketing mix elements and brand equity. Journal of the Academy of Marketing Science, 28(2).

33. Lawler, E.J(2000). An affect theory of social exchange. The American Journal of Sociology, 107(2), 321-352.

34. Bowerman, B.L, Kochler,A \& Pacj,D.J (1990). Forecasting time series with increasing seasonal variation. Journal of Forecasting Banner, 9(5), 419-436.

35. [35] Draper, N.R \& Smith,H (1981). Applied regression analysis (2ne edition) New York: Wiley.

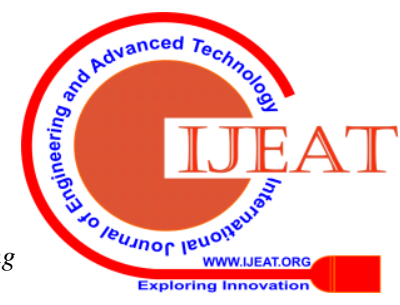


36. Cronin, J., Brady,M.K \& Hult,T.M(2000). Assessing the effects of quality, value and customer satisfaction on consumer behavioural intentions in service environments. Journal of Retailing, 76(2), 193218.

37. Jesri,P.Ahmadi \& Fatehipoor, F,H(2013). Effects of relationship marketing on consumer loyalty. Interdisciplinary Journal of Contemporary Research in Business, 4(11), 304-312.

38. Shaari,H\& Ahmad,I.S(2017). Brand resonance behaviouramong online brand community. International Review of Management and Marketing, 7(1).

39. Chiou,J.S (2004). The antecedents of consumer loyalty towards internet service providers. Journal of Information and Management, 41(6). 685-695.

40. Kim,J.,Morris,J.D \& Swait,J (2008). Antecedents of true brand loyalty. Journal of Advertising, 37, 99- 117.

41. Yu,H\& Chang, Y.T (2013). How to influence the brand attitude of the audience by micro films. Journal of Promotion Management.

\section{AUTHORS PROFILE}

Dr. V. S. Divyasre, has got a right blend of teaching and industrial experience. She is currently working as Assistant Professor in SRM Institute of Science and Technology in the Department of Business Administration. Her total teaching experience is around 4 years. Academic qualifications are B.E., M.B.A., Ph.D(Business Administration) and SET qualified. She has already published 6 research papers in Scopus Indexed and UGC refereed Journals. She has presented several papers and has participated in workshops and seminars organized by prestigious Institutions like IIT.

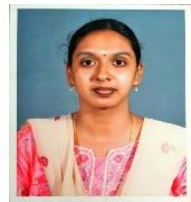

Dr.J.Ramya, obtained doctoral degree from College of Engineering (CEG) Guindy, Anna University. She holds a master's degree in business administration from College of Engineering (CEG) Guindy, Anna University and a bachelor's degree in computer science engineering from Avinashilingam Deemed University. Dr.J.Ramya works in SRM Institute of science and technology as Assistant Professor and has several years work experience in the areas of teaching, research and administration. She has authored nearly seven international publications on varied management subjects. She is a member of Indian Management Association. Her current research interests include enhancing customer experience for organized retailing customers and dynamic pricing strategies. 